\title{
Disinfection, sterilization, and antisepsis: Principles, practices, current issues, new research, and new technologies
}

\author{
William A. Rutala PhD, MPH, CIC ${ }^{\mathrm{a}, *}$, David J. Weber MD, MPH ${ }^{\mathrm{a}, \mathrm{b}}$ \\ ${ }^{a}$ Division of Infectious Diseases, University of North Carolina School of Medicine, Chapel Hill, NC \\ ${ }^{\mathrm{b}}$ Hospital Epidemiology, University of North Carolina Hospitals, Chapel Hill, NC
}

Health care-associated infections are an important source of morbidity and mortality, with an estimated 1.7 million infections and 99,000 deaths annually in the United States. ${ }^{1}$ The major source of health care-associated pathogens is thought to be the patient's endogenous flora, but an estimated $20 \%$ are acquired via other transmission routes such as the environment, and $20 \%-40 \%$ are attributed to crosstransmission via the contaminated hands of health care personnel. ${ }^{2}$

In the United States in 2010, there were 51.4 million inpatient surgical procedures and an even larger number of invasive medical procedures performed. ${ }^{3}$ For example, there are at least 18 million gastrointestinal endoscopies per year. ${ }^{4}$ Each of these procedures involves contact by a medical device or surgical instrument with a patient's sterile tissue of mucous membranes. Failure to properly disinfect or sterilize medical devices (eg, gastrointestinal endoscopes) and surgical instruments may lead to transmission via this device. ${ }^{5}$ Achieving disinfection and sterilization by disinfectants and sterilization practices are essential for ensuring that medical and surgical instruments do not transmit infectious pathogens to patients. Although the basic principles of high-level disinfection of semicritical (defined as those that touch mucous membranes) and critical items (defined as those that touch sterile tissue) have not changed, new practices, products, issues, technologies, and research continue to be introduced. Seven articles in this Special Issue focus on medical instrument reprocessing to include: cleaning (Alfa), biofilms (Alfa), outpatient care facilities (Bringhurst), high-level disinfectants and sterilization technologies (Rutala/Weber), adopting new technologies (Seavey), endoscope reprocessing and new developments (Rutala/ Weber), as well as reprocessing other semicritical items and the infection risk (Rutala/Weber).

In addition, low-level disinfectants are used for disinfection of noncritical environmental surfaces and equipment in health care facilities. Their use is supported by excellent evidence in the scientific literature that contaminated environmental surfaces and noncritical

\footnotetext{
* Address correspondence to William A. Rutala, PhD, MPH, CIC, Division of Infectious Diseases, University of North Carolina School of Medicine, 130 Mason Farm Rd, Bioinformatics Bldg, CB\#7030, Chapel Hill, NC 27599-7030.

E-mail address: brutala@med.unc.edu (W.A. Rutala).

Conflicts of interest: Dr. Rutala is a consultant to PDI (Professional Disposables International), Advanced Sterilization Products (ASP) and on an advisory board for Kinnos. Dr. Weber is a consultant to PDI and Germitec.
}

patient care items play an important role in the transmission of several key health care-associated pathogens including methicillinresistant Staphylococcus aureus, vancomycin-resistant Enterococcus, Acinetobacter, norovirus, and Clostridium difficile. All these pathogens have been demonstrated to persist in the environment for days to weeks (in some cases months), frequently contaminate the environmental surfaces in rooms of colonized or infected patients, transiently colonize the hands of health care personnel via contact with the environment of patients, are transmitted by health care personnel to patients, and cause outbreaks in which environmental transmission was deemed to play a role. Further, admission to a room in which the previous patient had been colonized or infected with methicillinresistant $S$ aureus, vancomycin-resistant Enterococcus, Acinetobacter, or $C$ difficile, has been shown to be a risk factor for the newly admitted patient to develop colonization or infection. ${ }^{6}$ Therefore, surface disinfection of noncritical environmental surfaces and medical devices (defined as those that contact intact skin) is one of the important infection prevention strategies to prevent pathogen transmission. Six articles in this Special Issue focus on the role on environmental surfaces and disease transmission to include: continuous room decontamination technologies (Weber et al), portable equipment and floors as sources of transmission (Donskey), "no touch" decontamination devices (Donskey), best practices for surface disinfection of environmental surfaces (Rutala/Weber), emerging infectious diseases (eg, Ebola, Candida auris), germicide susceptibility (Weber et al), and is there a relationship between germicidal use and antibiotic resistance (Weber et al).

Hand hygiene is a cornerstone of preventing transmission from health care personnel to patients via contaminated hands and from contaminated environmental surfaces and medical devices via health care personnel hands to patients. The association between improved hand hygiene compliance from low to higher rates and reductions in health care-associated infection rates has been well described. ${ }^{7-9}$ In this Special Issue, Dr Boyce provided a comprehensive review of current issues in hand hygiene such as optimum dose of alcohol-based handrub that should be applied, the impact of hand size and alcoholbased handrub dry times on efficacy, monitoring hand hygiene, and the ideal hand hygiene technique.

In addition to hand hygiene, antiseptics are widely used in health care for skin antisepsis for invasive procedures (eg, placement of a 
central venous catheter), skin antisepsis of patients and surgical staff prior to surgery, daily bathing of patients residing in an intensive care unit, and nasal decolonization. In this Special Issue, Dr Boyce reviews the scientific literature regarding the best products for preoperative bathing, surgical site preparation, surgical hand antisepsis, daily antiseptic bathing of patients in the intensive care unit and in non-intensive care unit patients, and skin antisepsis during intravascular access. Dr Septimus reviews the strategies to reduce surgical site infections due to $S$ aureus focusing on nasal decolonization.

This Special Issue was developed from a symposium presented at the APIC annual meeting in 2018. We are deeply indebted to the authors for their lifetime contributions to disinfection, sterilization, and/or antisepsis and for the time they devoted to this work and sharing their expertise.

\section{References}

1. Klevens RM, Edwards JR, Richards CL Jr, Horan TC, Gaynes RP, Pollock DA, et al. Estimating health care-associated infections and deaths in the US hospitals, 2002. Public Health Rep 2007;122:160-7.
2. Weinstein RA. Epidemiology and control of nosocomial infections in adult intensive care units. Am J Med 1991;9(Suppl 3B):179-84.

3. Fields R. Outpatient surgeries outnumber inpatient surgeries at $53 \mathrm{M}$ procedures a year. September 27, 2010. Available from: https://www.beckersasc.com/news-analysis/outpatient-surgeries-outnumber-inpatient-surgeries-at-53m-procedures-ayear.html. Accessed January 2019.

4. Peery AF, Dellon ES, Lund J, Crockett SD, McGowan CE, Bulsiewicz WJ, et al. Burden of gastrointestinal disease in the United States: 2012 update. Gastroenterology 2012;143:1179-87.

5. Rutala WA, Weber DJ. Disinfection, sterilization and antisepsis: an overview. Am J Infect Control 2019;47 (Suppl):A3-9.

6. Rutala WA, Weber DJ. Best practices for disinfection of noncritical environmental surfaces and equipment in healthcare facilities: a bundle approach. Am J Infect Control 2019;47 (Suppl):A96-105.

7. Boyce JM, Pittet D, Healthcare Infection Control Practices Advisory Committee, HICPAC/SHEA/APIC/IDSA Hand Hygiene Task Force. Guideline for hand hygiene in health-care settings. Recommendations of the Healthcare Infection Control Practices Advisory Committee and the HICPAC/SHEA/APIC/IDSA Hand Hygiene Task Force. Society for Healthcare Epidemiology of America/Association for Professionals in Infection Control/Infectious Diseases Society of America. MMWR Recomm Rep 2002;51:1-45.

8. Pittet D, Hugonnet S, Harbarth S, Mourouga P, Sauvan V, Touveneau S, et al. Effectiveness of a hospital-wide programme to improve compliance with hand hygiene. Infection Control Programme. Lancet 2000;356:1307-12.

9. Sickbert-Bennett EE, DiBiase LM, Willis TMS, Wolak ES, Weber DJ, Spears TG, et al. Improved hand hygiene does reduce infections. Emerg Infect Dis 2016;22:1628-30. 